Historic, Archive Document

Do not assume content reflects current scientific knowledge, policies, or practices. 

794.4

F $7632 \mathrm{~V}$

United States

(4) Department of

Agriculture

Forest Service

Rocky Mountain

Forest and Range

Experiment Station

Fort Collins,

Colorado 80526

Research Paper

RM-234

Donald C. Markstrom, Dennis M. Donnelly, Janet L. Van Glarik, Richard O. Woodfin, Jr., and Harold E. Worth

ivis

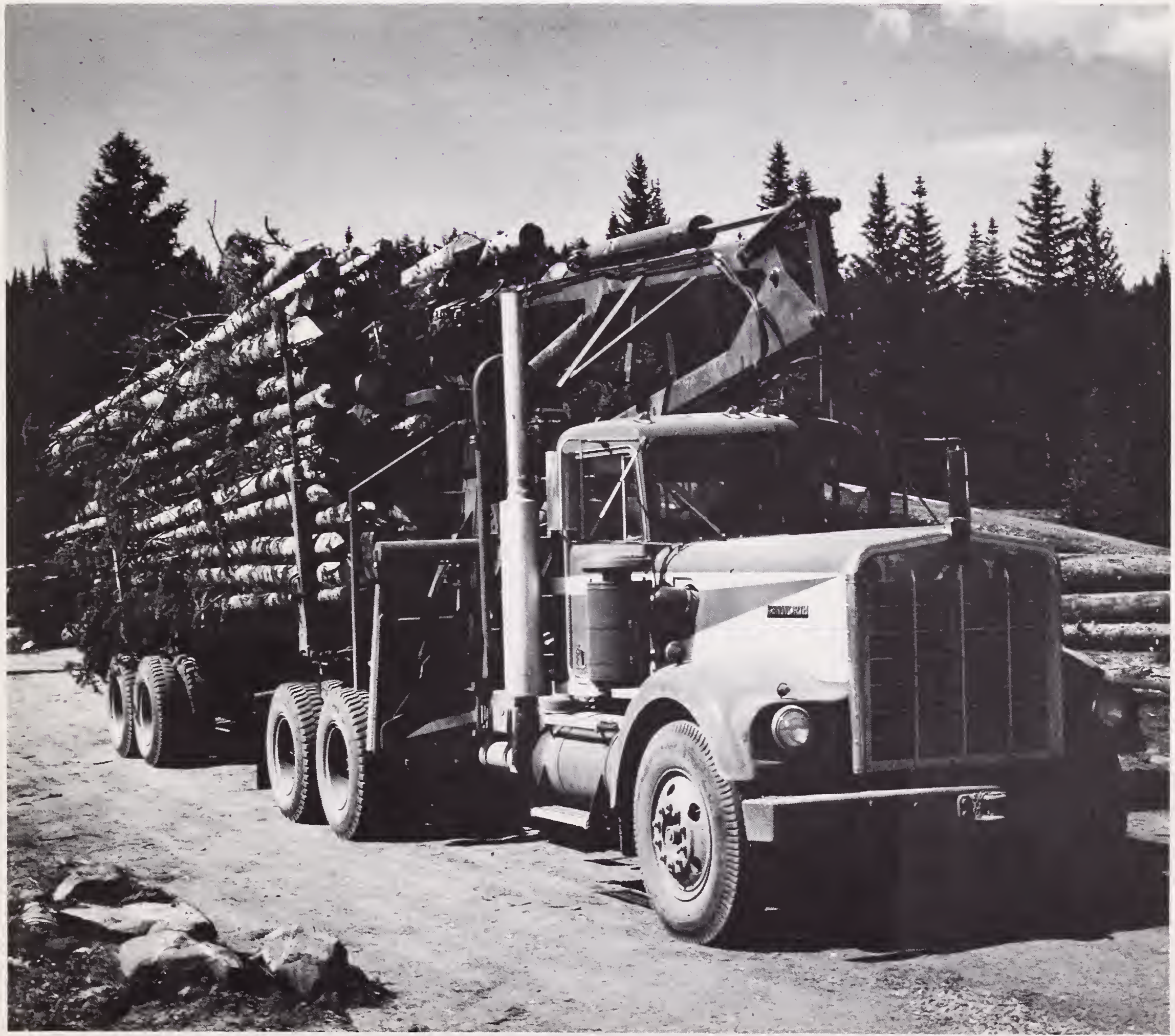




\title{
Cord, Volume, and Weight Relationships for Small Ponderosa Pine Trees in the Black Hills ${ }^{1}$
}

\author{
Donald C. Markstrom, Wood Technologist \\ Dennis M. Donnelly, Systems Analyst \\ Janet L. Van Glarik, Forestry Technician \\ Rocky Mountain Forest and Range Experiment Station ${ }^{2}$ \\ Richard O. Woodfin, Jr., Program Manager \\ Pacific Northwest Forest and Range Experiment Station ${ }^{3}$ \\ and \\ Harold E. Worth, Principal Market Analyst \\ Rocky Mountain Forest and Range Experiment Station ${ }^{2}$
}

\begin{abstract}
Wood volume and oven-dry weight of wood and of bark can be reliably estimated from the combined green weight of wood and bark, with $97 \%$ of the variation being accounted for in predicting wood volume (cubic feet), $99 \%$ in predicting oven-dry weight of wood, and $91 \%$ in predicting oven-dry weight of bark. Simulation of random truckloads of small roundwood show that this class of material can be weight scaled by either ratio weight or regression weight-scaling methods based on a small number of sample loads. The average wood volume in sample cords was 72.8 cubic feet, for bolts from 5-7 inch trees, with a coefficient of variation of $3.2 \%$.
\end{abstract}




\title{
Cord, Volume, and Weight Relationships for Small Ponderosa Pine Trees in the Black Hills
}

\author{
Donald C. Markstrom, Dennis M. Donnelly, Janet L. Van Glarik, \\ Richard O. Woodfin, Jr., and Harold E. Worth
}

\section{Management Implications}

Timber below sawtimber size is commonly harvested in commercial thinning, pulpwood, or multiproduct sales. It is typically marketed as pulpwood or, increasingly, as firewood. There is also interest in this class of timber as raw material for structural flakeboard. For each of these purposes, the most important characteristic of the trees is the amount of wood substance they contain when dry. Because the amount of dry wood substance in a standard cord varies with the diameters of the bolts in the cord, the cord is not a very exact unit of measure. A cord comprised of bolts with a larger average diameter contains more dry wood substance than one with bolts of smaller average diameter.

The logical alternatives to cord measurement are bolt-volume scaling and weight scaling. Volume scaling has the advantage of measuring the wood substance in each bolt directly with a high degree of precision. Its disadvantages are the time it takes and the cost. Weight scaling, while potentially less accurate, is fast and relatively inexpensive.

Almost 500 small ponderosa pine trees (below sawtimber size) were sampled at 10 sites, in the Black Hills National Forest, to determine the relationships between standard cord volume (128 cubic feet) actual volume of the wood, and dry weight of the wood. The volume of wood in a standard cord in this size class did not vary much, averaging 72.8 cubic feet of green wood. The weight of green cordwood was shown to be a reliable indicator of wood volume. These research results should help buyers and sellers of small roundwood to decide which of these systems is most cost effective for their purposes.

\section{Introduction}

Most ponderosa pine (Pinus ponderosa) small roundwood in the Black Hills has been marketed for pulpwood and post material on a cord basis. This method, while convenient, has led to disputes between some buyers and sellers about the actual volume of solid wood in a cord, which is the bulk volume of a stack of cordwood 4 feet by 4 feet by 8 feet. Important factors affecting the solid wood volume in a cord include bolt diameter, bark thickness, and bolt straightness. Defect deductions are occasionally made for fire scar and crook, depending upon severity and extent. Rot generally is not severe enough in these size trees to warrant a deduction.

A structural flakeboard manufacturing facility has been proposed for the Black Hills (Black Hills National Forest Product News 1980). Reportedly, this plant could increase the demand for small roundwood annually by as much as 100 thousand cords. Development of weight-scaling procedures based on this research might reduce the cost of sales administration if such a plant were built.

Myers (1960) reported research on volume-weightmoisture relationships for ponderosa pine in the Black Hills. He found that the oven-dry weight of the merchantable boles of trees from 6 to 11.5 inches d.b.h. was closely correlated with their cubic foot volumes. There was no significant difference in the density (dry weight per cubic foot) of trees from thinned and unthinned stands nor any correlation between wood density and the following variables: form quotient, age on stump, crown class, crown diameter, crown length, percent of tree length in crown, site index, and stand basal area. The average specific gravity and density were 0.393 and 24.5 pounds per cubic foot, respectively.

Landt and Woodfin (1959) reported that the specific gravity for trees younger than 100 years, in the Black Hills, averaged 0.398; specific gravity for older trees averaged 0.417 . The younger trees had a greater green weight per cubic foot because of higher moisture content. The younger trees also had a higher proportion of sapwood. An average cord sampled from trees ranging from 6 to 12.9 inches d.b.h. contained 75.9 cubic feet of wood. Other research in the Black Hills showed that wood specific gravity decreased with increasing height up the merchantable stem (Markstrom and Yerkes 1972).

Yerkes (1966) developed regression formulas to predict the density of ponderosa pine sawlogs. The important variables included diameter inside the bark (d.i.b.) of the small end and average moisture content. Formulas to predict net cubic-foot volume of green ponderosa pine logs included total log weight, log diameter inside the bark at the small end, and percent defect.

Donnelly and Barger (1977) evaluated three weightscaling methods-sample-stick, ratio-weight, and regression-weight scaling-for southwestern ponderosa pine timber. Regression-weight scaling was found to be more precise than the other two. The most precise 
regression equation that was practical to apply included net load weight and log count. However, other factors that must be considered are sales area, seasonal changes in moisture content, log length mix, and the young-growth/old-growth mix.

Much additional weight-scaling research has been reported in the literature, largely for southern pine and hardwood sawlogs, veneer logs, and pulpwood (Blair 1965, Fasick et al. 1974, Guttenberg and Fasick 1973, Guttenberg et al. 1960, Row and Fasick 1966, Row and Guttenberg 1966, Schumacher 1946, Taras 1956, Tyre et al. 1973, Weldon 1967, Wensel 1974). Lothner et al. (1974) reported the weight per unit volume for aspen pulpwood during the summer and winter in northern Minnesota.

\section{Study Objectives}

The overall objectives of this study were to develop information about volume-weight-moisture relationships of the trees that would be useful in weight scaling small roundwood and to determine methods that might be used to estimate truckload cubic volumes based on truckload weights.

Specific objectives were to:

1. Determine the effects of tree diameter and sampling area on:

a. green weight of wood and bark per cubic foot of wood,

b. moisture content of the wood, and

c. moisture content of the bark.

2. Develop regression equations to predict the volume of wood, oven-dry weight of wood, and ovendry weight of bark of the trees based on the green weight of the wood and bark.

3. Determine the actual volume of wood in a standdard 128-cubic-foot cord.

4. Determine the effect of size of truckload upon the ratio weights and the regression-weight equations.

5. Determine the effect of number of truckloads upon the ratio weights and the regression-weight equations.

A ratio weight or cubic volume of wood per unit weight of wood and bark is actually a form of a simple linear regression equation where the constant term is zero.

\section{Study Area and Methods}

A total of 489 live trees were sampled on 10 plots throughout the Black Hills National Forest (fig. 1). These plots were selected to be representative of those to be harvested throughout the Black Hills. The sample trees on each plot were selected as to stem characteristics to benefit future sawtimber production. Three percent had either forked or dead tops. Approximately equal numbers of trees were sampled at each site in the 5-, 6-, and 7-inch d.b.h. classes. Ninety-six percent of the trees contained at least two 100-inch pulp bolts with a minimum d.i.b. of $3-1 / 2$ inches. The other $4 \%$ contained at least one full bolt. Characteristics of the sample trees are shown in table 1.

The field procedure was to measure diameter at breast height, fell, and buck-selected trees into 100-inch bolts and a short bolt, if necessary, to include the 3-1/2 inch top d.i.b. Total height, height to 4-inch top d.i.b., diameter inside bark at the end of each bolt, length of the short bolt, and weight of each bolt were measured immediately after felling each tree. The tree volumes were calculated from the bolts using Smalian's formula, and assuming: (1) utilization to a 3-1/2 inch top d.i.b. and (2) utilization of 100-inch bolts only. All of the 100-inch bolts for each plot were stacked in a portable rick to estimate cord volume immediately after weighing (fig. 2). The number of cords per plot ranged from 2.01 to 2.90 .

Sixty of the above trees-two randomly selected within each diameter class at each site-had 1-inchthick disks cut at 100 -inch intervals from stump height to $3-1 / 2$ inches d.i.b. Age was determined from the disk taken from approximately 1 foot above ground and growth rate from the disk taken at approximately 9 feet above ground. The bark and wood of each disk, after being separated and weighed, were oven-dried at $103^{\circ} \mathrm{C}$ for 24 hours and were reweighed. The bark and moisture content values of each disk were calculated and then weighted by disk diameter to reflect a single value for each tree.

The green weight of wood and bark per cubic foot of wood for the tree was calculated by adding the weights of all bolts (to the 3-1/2 inch d.i.b. top) and dividing by the cubic volume. Tree specific gravity was calculated as follows:

$$
S G=\frac{(A)(B)(100)}{(C+100)(D)}
$$

where

SG = specific gravity of the tree

$\mathrm{A}=$ green weight of wood and bark per cubic foot of wood

$\mathrm{B}=$ proportion of green wood to total green wood and bark by weight

$\mathrm{C}=$ percent moisture content of wood based on oven-dry weight

$\mathrm{D}$ = weight per cubic foot of water: 62.4 pounds.

Table 1.-Characteristics of sample trees

\begin{tabular}{lrrr}
\hline Tree characteristics & \multicolumn{2}{c}{ Mean \pm SD } & $\begin{array}{r}\text { Number } \\
\text { of trees }\end{array}$ \\
\hline Diameter (inches d.b.h.) & $6.5 \pm$ & 0.8 & 489 \\
Total height (feet) & $42.8 \pm$ & 7.9 & 489 \\
Height to 31/2 inch top d.i.b. (feet) & $27.8 \pm$ & 7.6 & 489 \\
Volume to 31/2 inch top d.i.b. (cubic & & & \\
$\quad$ feet) & $3.90 \pm$ & 1.61 & 489 \\
Volume, utilizing 100-inch bolts only & & & \\
$\quad$ (cubic feet) & $3.57 \pm$ & 1.60 & 489 \\
No. of 100-inch bolts per tree & $2.9 \pm$ & 0.9 & 489 \\
Age at stump (years) & $82 \pm$ & 9 & 60 \\
Increment growth rate (rings per & $26 \pm$ & 4 & 60 \\
$\quad$ inch) & $12.4 \pm$ & 1.4 & 60 \\
Percent bark, green weight basis & $17.2 \pm$ & 2.1 & 60 \\
Percent bark, oven-dry weight basis & $0.395 \pm 0.029$ & 60 \\
Specific gravity of wood & & & \\
\hline
\end{tabular}




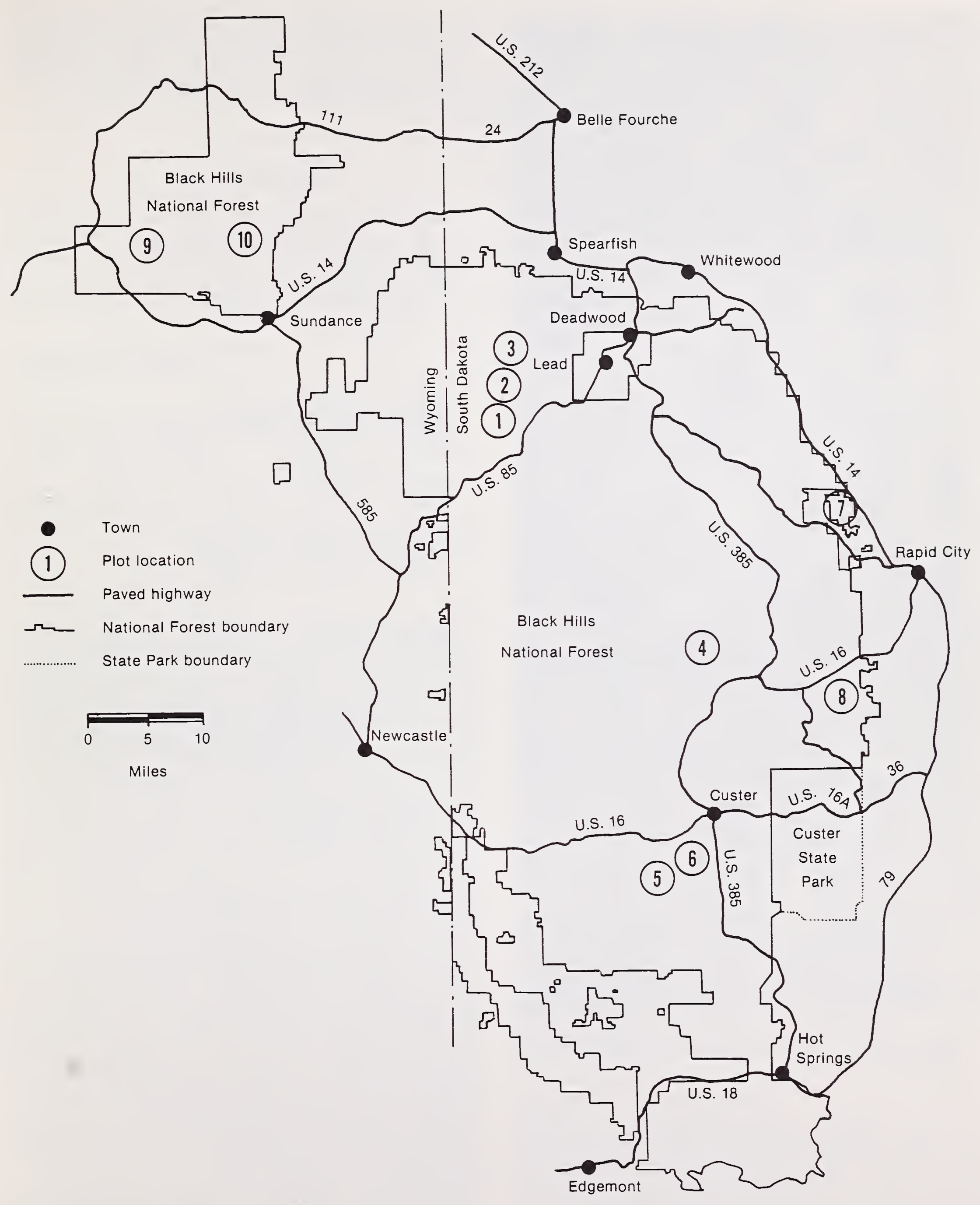

Figure 1.-Study trees were selected from 10 sampling plots in the Black Hills of South Dakota and Wyoming. 


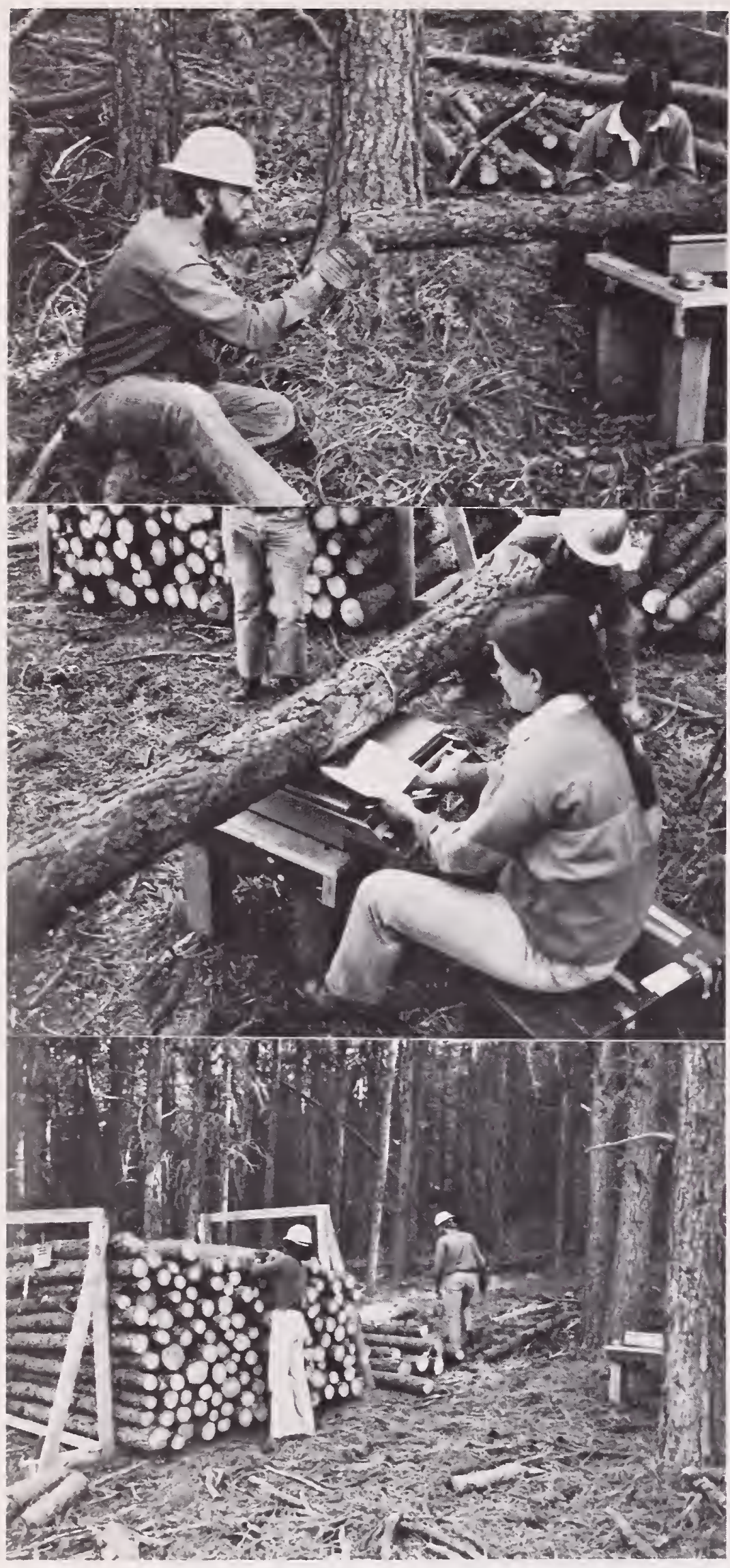

Figure 2.-All bolts were measured for diameter inside bark and length and weighed. The 100 -inch bolts were placed in a rick to determine cord volume.

Three characteristics of the trees that are important for weight scaling are (1) green weight of the wood and bark per cubic foot of wood, (2) percent moisture content of the bark, and (3) percent moisture content of the wood. Each of these were analyzed factorially to determine the effect of tree diameter, general sampling areas, and plot locations within each sampling area.
Four general sampling areas-northern, central, and southern Black Hills and the Bearlodge Mountainswere classified to reflect both possible variations among plot locations and existing industry production and marketing patterns for small roundwood.

\section{Results and Discussion}

The factorial analyses indicated that tree diameter and sampling area did not significantly affect either the green weight of wood and bark per cubic foot of wood or the moisture contents of the bark and wood. The overall means and standard deviations for these tree characteristics were:

\section{Mean \pm SD Number of trees}

Green weight of wood and bark per cubic foot of wood (pounds per cubic foot)

$$
64.6 \pm 4.4
$$

Moisture content of wood (percent of oven-dry weight)

$132 \pm 13$

60

Moisture content of bark

(percent of oven-dry weight) $64 \pm 14$

60

However, factorial analyses did indicate that plot location within the sampling areas did significantly affect the above characteristics. The variation between and within plots of each sampling area is shown by the plot means and standard deviations (table 2). The practical effect of plot location within sampling area may be interpreted by comparing the dollar value of a green ton of wood and bark from two plots in the northern sampling area. One ton of wood and bark would contain from 30.0 to 31.8 cubic feet of wood, based on green weight of wood and bark ranging from 66.6 to 63.0 pounds per cubic foot. The corresponding values per green ton of wood and bark would range from $\$ 12.60$ to $\$ 13.36$, assuming the wood to be worth $\$ 42.00$ per cunit delivered to a plant site.

The possibility was recognized that some site-related factors not measured in this study could affect both green weight and the moisture content. Yerkes (1967) found that ponderosa pine trees on a north slope and a well-drained flat averaged from $8 \%$ to $14 \%$ higher moisture content than those on a ridgetop, a south slope, and a beaver-pond fill. Variation in specific gravity with site is another possibility. However, the average specific gravity of 0.395 for the wood of the trees in this study was similar to 0.398 determined by Landt and Woodfin (1959) and 0.393 by Myers (1960) for Black Hills ponderosa pine.

Equations to predict cubic volume and oven-dry weight of wood and oven-dry weight of bark of the trees were developed and evaluated in conjunction with the previous analyses of variance, as follows: 
Table 2.-Green weight of wood and bark (pounds) per cubic foot of green wood and the moisture content of the wood and bark (percent of ovendry weight) for each plot

\begin{tabular}{lcccc}
\hline Sampling area & Plot number & $\begin{array}{c}\text { Green weight of wood } \\
\text { and bark per cu ft } \\
\text { of green wood }\end{array}$ & \multicolumn{2}{c}{ Moisture content } \\
\cline { 5 - 6 } & & & Wood & Bark \\
\cline { 5 - 6 } Northern & 1 & $66.6 \pm 3.5$ & $138 \pm 10$ & $75 \pm 10$ \\
& 2 & $63.0 \pm 4.6$ & $127 \pm 12$ & $67 \pm 10$ \\
Central & 3 & $65.9 \pm 4.4$ & $132 \pm 11$ & $66 \pm 19$ \\
& 4 & $63.8 \pm 4.5$ & $140 \pm 8$ & $68 \pm 9$ \\
Southern & 7 & $65.4 \pm 4.3$ & $125 \pm 11$ & $45 \pm 6$ \\
& 8 & $65.9 \pm 3.1$ & $126 \pm 13$ & $48 \pm 9$ \\
Bearlodge & 5 & $62.2 \pm 3.9$ & $119 \pm 17$ & $62 \pm 13$ \\
& 6 & $64.0 \pm 4.3$ & $145 \pm 10$ & $69 \pm 12$ \\
& 9 & $64.6 \pm 4.7$ & $127 \pm 6$ & $63 \pm 7$ \\
& 10 & $65.0 \pm 4.8$ & $140 \pm 6$ & $73 \pm 14$ \\
\hline
\end{tabular}

For volume of wood (cubic feet)

$\mathrm{S}_{\mathrm{y} \cdot \mathrm{x}} \quad \mathbf{R}^{2} \quad \mathbf{n}$

$$
\mathrm{Y}_{1}=\underset{(0.030)}{0.182}+\underset{(0.0001)}{0.015 \mathrm{X}_{1}} \quad 0.261 \quad 0.97 \quad 489
$$

For oven-dry weight of wood

$$
\mathrm{Y}_{2}=\underset{(1.666)}{0.635}+\underset{(0.006)}{0.382 \mathrm{X}_{1}} \quad \begin{array}{lll}
5.543 & 0.99
\end{array}
$$

For oven-dry weight of bark

$$
\mathrm{Y}_{3}=\underset{(0.757)}{2.369}+\underset{(0.003)}{0.065 \mathrm{X}_{1}}
$$

$$
2.518 \quad 0.91
$$

Where:

$$
\begin{aligned}
\mathrm{Y}_{1}= & \text { wood volume (cubic feet) } \\
\mathrm{Y}_{2}= & \text { oven-dry weight of wood (pounds) } \\
\mathrm{Y}_{3}= & \text { oven-dry weight of bark (pounds) } \\
\mathrm{X}_{1}= & \text { total green tree weight of wood and bark } \\
& \text { (pounds) } \\
\mathrm{S}_{\mathrm{y} \cdot \mathrm{x}}= & \text { standard deviation of wood volumes or oven- } \\
& \text { dry weights about the regression } \\
\mathrm{R}^{2}= & \text { coefficient of determination } \\
\mathrm{n} & =\text { number trees }
\end{aligned}
$$

The values in parenthesis under each coefficient are the respective standard errors.

The combined green weight of wood and bark was the single variable that best predicted the cubic volume of wood and the oven-dry weights of wood and bark in the tree. The addition of diameter at breast height did not substantially improve the prediction. Plotting of residual values (difference between predicted and actual values) for each sampling area indicated that the prediction formula consistently fitted the data. Figures 3,4 , and 5 show the regression line and the $95 \%$ confidence intervals of the single tree values predicted from the total weight of wood and bark.

The volume of wood per cord sampled from the 10 plots was $72.8 \pm 2.3$ cubic feet (average \pm 1 standard deviation). The corresponding green weight per cord was 4,676 \pm 151 pounds. These averages are less than the 75.9 cubic feet and 4,950 pounds per cord reported by Landt and Woodfin (1959). The lower values per cord and small variances in the present study may be partially attributed to the smaller trees sampled.

The preceding regression equations and green weight per cord were based on trees sampled at one time of the year-in September. Seasonal variation in tree water content has been reported and possibly could affect the regression equation and the green weight per cord (Yerkes 1967).

\section{Truckload Simulation}

The purpose of the truckload simulation was to provide a first estimate of statistical values necessary for implementing truckload weight scaling of small roundwood. The simulations were based on present industry practice of either cutting small roundwood trees into 100-inch bolts and hauling them to a rail siding for shipment to distant pulpmills or cutting the trees into tree length logs and hauling them to a local processing plant. Consequently, loads were simulated that contained trees only and that contained bolts only. Tree loads were made up of 100 -inch bolts and bolts less than 100 inches so that simulated tree-length logs extended to a 3.4-inch top d.i.b. Bolt loads contained only 100-inch bolts, with each full bolt in a tree considered as an individual member of the population.

The load weight classes ranged from 5,000 pounds to 70,000 pounds at 5,000-pound intervals, with 25 loads and 50 loads simulated for each weight class. The weight classes were chosen to represent a range of load sizes that may be hauled in the Black Hills.

A uniform distribution random number generator was used to select trees or bolts to be included in a load to produce an equal likelihood of choosing any one of the 489 trees or 1,311 bolts. The last tree or bolt added to a load brought the weight to just at or above the appropriate weight class. Only results from the 25-load simulations are reported in this paper, because the results from the 25-load and 50-load simulations were similar. 


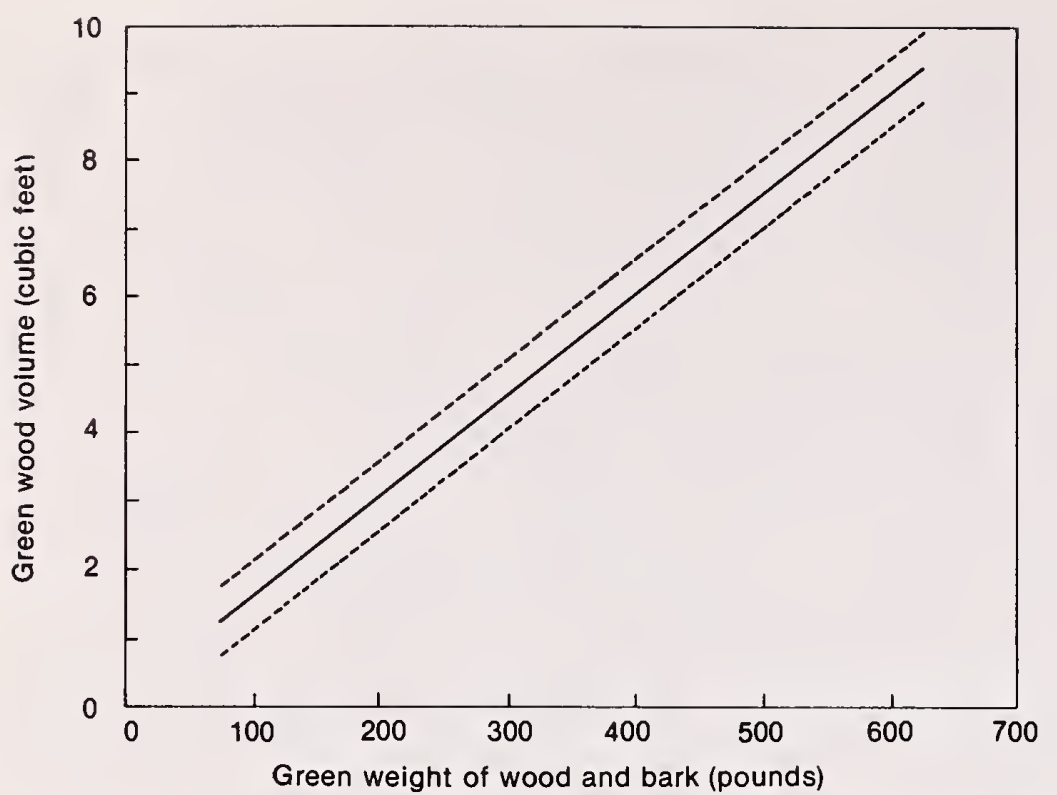

Figure 3.-Green wood volume of tree predicted from green weight of wood and bark, with $95 \%$ confidence interval of single tree values about linear regression line.

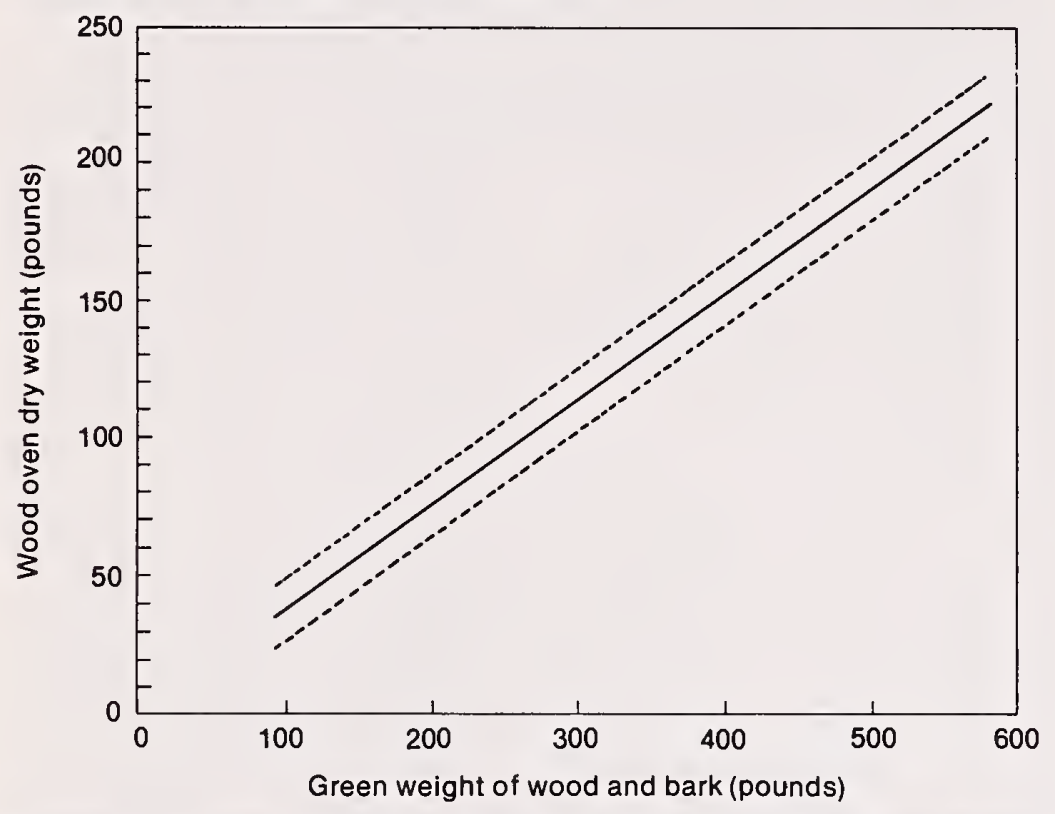

Figure 4.-Oven-dry weight of wood from tree predicted from green weight of wood and bark, with $95 \%$ confidence interval of single tree values about linear regression line.

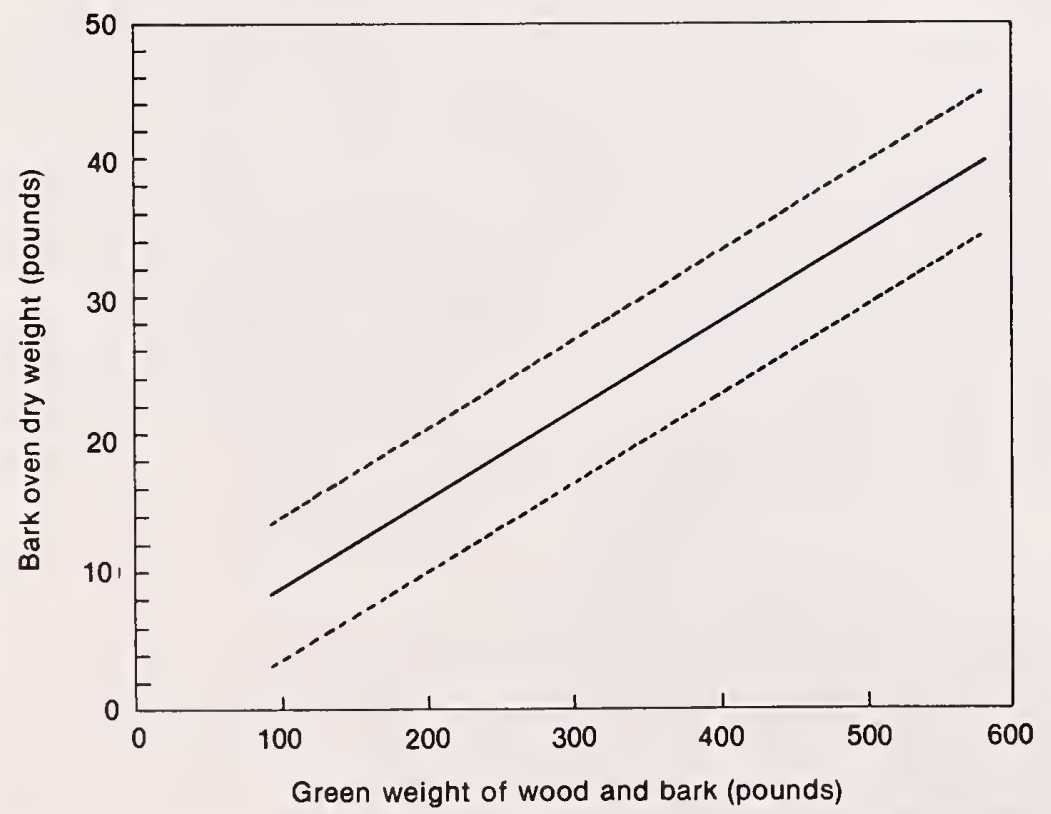

Figure 5.-Oven-dry weight of bark from tree predicted from green weight of wood and bark, with $95 \%$ confidence interval of single tree values about linear regression line.

\section{Ratio Weight Scaling}

One objective of simulating loads of different weights was to determine the effect of load size upon the ratio weight or cubic feet of green wood per 100 pounds of green wood and bark. The mean and standard deviation of the ratio weights for the individual 489 trees and 1,311 bolts were $1.555 \pm 0.111$ and $1.546 \pm$ 0.163. The means of the ratio weights for the truckloads of trees and bolts are similar to those of the individual trees and bolts, but the standard deviations for the truck loads are considerably less than those for the individual trees and bolts because of measuring variability of aggregated quantities (table 3).

Cubic-foot volumes for truckloads with different weights of trees and bolts were estimated using a mean ratio weight of 1.543 cubic feet per 100 pounds for tree loads and 1.555 for bolt loads. Simulated weights are at 25 loads per weight class.

\begin{tabular}{crr}
\multirow{2}{*}{$\begin{array}{c}\text { Truckload } \\
\text { weight }\end{array}$} & \multicolumn{2}{c}{ Volume of green wood } \\
\cline { 2 - 3 } pounds & Trees & Bolts \\
\cline { 2 - 3 } 5,000 & 154.1 & 77.8 \\
10,000 & 231.3 & 155.5 \\
15,000 & 308.4 & 233.3 \\
20,000 & 385.5 & 311.0 \\
25,000 & 462.6 & 388.8 \\
30,000 & 539.7 & 466.5 \\
35,000 & 616.8 & 544.3 \\
40,000 & 693.9 & 622.0 \\
45,000 & 771.0 & 699.8 \\
50,000 & 848.1 & 777.5 \\
55,000 & 925.2 & 855.3 \\
60,000 & $1,002.3$ & 933.0 \\
65,000 & $1,079.4$ & $1,010.8$ \\
70,000 & & $1,088.5$
\end{tabular}

\section{Regression Weight Scaling}

The following two equations for predicting the cubic volume of wood from the green weight of the wood and bark were developed. Equation [4] is based on samples of trees. Equation [5] is based on samples of bolts. The simulation included 25 loads per weight class.

$$
\begin{aligned}
& \mathrm{S}_{\mathrm{y} \cdot \mathrm{x}} \quad \mathbf{R}^{2} \\
& \mathrm{Y}_{1}=\underset{(0.371)}{0.279}+\underset{(0.0009)}{1.542 \mathrm{X}_{1}} \\
& \mathrm{Y}_{2}=\underset{(0.330)}{0.199}+\underset{(0.0008)}{1.554 \mathrm{X}_{1}} \\
& 3.272 \quad 0.99 \\
& 2.917 \quad 0.99
\end{aligned}
$$

Where:

$$
\begin{array}{ll}
\mathrm{X}_{1} & =\text { green weight of wood and bark in 100-pound } \\
\text { units } \\
\mathrm{Y}_{1}=\text { cubic feet of wood (trees) } \\
\mathrm{Y}_{2}=\text { cubic feet of wood (bolts) } \\
\mathrm{S}_{\mathrm{y} \cdot \mathrm{x}}=\text { standard deviation of wood volume about the } \\
\mathrm{R}^{2}=\text { cogression }
\end{array}
$$


Table 3.-Summary of ratio weights (cubic feet per 100 pounds)'

\begin{tabular}{lccccc}
\hline \multirow{2}{*}{$\begin{array}{l}\text { Simulated truckloads } \\
\text { of trees or bolts }\end{array}$} & \multicolumn{4}{c}{ Ratio weights per truckload } \\
\cline { 2 - 3 } & \multicolumn{2}{c}{ Means } & & Standard deviations \\
\cline { 2 - 3 } \cline { 5 - 6 } & Range & Average & & Range & Average \\
\hline Trees & $1.540-1.546$ & 1.543 & $0.006-0.029$ & 0.013 \\
Bolts & $1.553-1.557$ & 1.555 & $0.006-0.022$ & 0.011 \\
\hline
\end{tabular}

'Calculated by simulating 25 truckloads of trees and bolts at 5,000 -pound intervals from 5,000 to 70,000 pounds total load weight.

The values in parenthesis under each coefficient are the respective standard errors.

The two equations are nearly identical and predict similar truckload volumes. The high $\mathrm{R}^{2}$ values attest to the goodness of fit of the regression. The constant term for each of the equations is not statistically different from zero $(P=0.05)$. Consequently, ratio-weight scaling can be used.

\section{Application}

Truckload simulation has indicated low variation in the ratio weights and the regression equations predicting cubic volume of wood from the green weight of wood and bark. Calculation of sample size in the following example indicated that only 6 truckloads in a 500-load sale need to be sampled by the ratio weightscaling method to remain within a $2 \%$ allowable error at the $95 \%$ confidence level. The small number of sample loads required may be attributed to the uniformity of the trees in the diameter at breast height classes sampled and the narrow range of diameter at breast height sampled. A larger sample size would likely be needed for a field situation in which a wider range of diameter at breast height would be encountered in the trees to be utilized.

The number of sample loads required for a given sale can be approximated at the start of the sale using a coefficient of variation developed from data in this report. The number of sample loads should be recalculated based on sale data after a representative number of loads have been sampled. The number of truckloads required in the sample can be calculated as follows:

$$
\mathrm{n}=\frac{1}{\left(\frac{\mathrm{PE}}{\mathrm{CV}}\right)^{2}\left(\frac{1}{\mathrm{t}^{2}}\right)+\frac{1}{\mathrm{~N}}}
$$

where

$$
\begin{aligned}
& \mathrm{n}=\text { number of truckloads in the sample } \\
& \mathrm{N}=\text { estimated total number of loads in sale } \\
& \mathrm{PE}=(\mathrm{E} / \overline{\mathrm{x}}) \times 100 \% \\
& \mathrm{CV}=\mathrm{S} / \overline{\mathrm{x}} \\
& \overline{\mathrm{x}}=\text { mean of ratio estimator in cubic feet of wood } \\
& \text { per } 100 \text { pounds of wood and bark }
\end{aligned}
$$

$\mathrm{t}=$ Student's $\mathrm{t}$ value; for $\mathrm{n}$ larger than $25, \mathrm{t} \cong 2$

$\mathrm{E}=$ one-half the width of the desired confidence interval; that is, the precision for the sample estimate of the mean in cubic feet of wood per 100 pounds of wood and bark

$\mathrm{S}$ = estimate of standard deviation of the ratio estimation of the population in cubic feet of wood per 100 pounds of wood and bark.

The following steps illustrate the computation of sample size with examples:

1. Estimate the average truckload ratio weight in cubic feet of wood per 100 pounds of wood and bark from experience or a presale sample.

$$
\begin{aligned}
\bar{x} & =\text { average truckload ratio weight } \\
& =1.540 \text { cubic feet per } 100 \text { pounds (table } 3 \text { ). }
\end{aligned}
$$

2. Estimate truckload ratio weight standard deviation from experience or a presale sample.

$\mathrm{S}=$ truckload standard deviation

$=0.029$ cubic feet per 100 pounds (table 3).

3. Compute estimated percent coefficient of variation by dividing $\mathrm{S}$ by $\overline{\mathrm{x}}$.

$$
C V=\frac{S}{\bar{x}} \times 100 \%=\frac{0.029}{1.540} \times 100 \%=1.88 \%
$$

4. Decide on allowable percent error in sale estimate. Normally, this would be $2 \%, 3 \%$, or $4 \%$.

$$
\mathrm{PE}=2 \%
$$

5. Estimate total number of truckloads in the sale (N) from estimated total sale cruise volume and estimated average load size. If estimated total cruise volume on sale equals 360,000 cubic feet and average load size equals 720 cubic feet,

$$
\mathrm{N}=\frac{360,000}{720}=500 \text { loads }
$$

6. Substituting the above quantities and determining the proper $t$ value through trial and error, the number of truckloads to sample (n) was calculated as follows:

$$
\mathrm{n}=\frac{1}{\left(\frac{2}{1.88}\right)^{2}\left(\frac{1}{(2.571)_{2}}\right)+\frac{1}{500}}=5.77
$$

The minimum sample size using the next higher whole number is 6 .

The allowable error of $2 \%$ signifies the following in terms of dollars to the buyers and sellers: truckloads containing 46,750 pounds of green wood and bark would average 720 cubic feet in the application example; the actual volume of wood on these truckloads 
would range from 705.6 to 734.4 cubic feet, assuming a $2 \%$ allowable error at the $95 \%$ confidence level; the value of the wood per truckload based on ratio weight scaling would be $\$ 302.40$, assuming wood to be worth $\$ 42.00$ per cunit; the values of the same truckloads based on cubic volume measurements could range from $\$ 296.35$ to $\$ 308.45$.

\section{Conclusions}

The results of this study indicate that cubic feet volume and oven-dry weight of wood and oven-dry weight of bark can be estimated from the combined green weight of the bark and wood. Green weight alone accounted for $97 \%$ of the variability (coefficient of determination) in predicting cubic volume of wood, $99 \%$ in predicting the oven-dry weight of wood, and $91 \%$ in predicting the oven-dry weight of bark.

Simulated truckloads of roundwood from 5- to 7-inch d.b.h. trees indicated that this material could be weight scaled with relatively few sample loads from a timbersale area. However, the ratio weights and regression equations given in this report apply only to the study samples. Before they are used for other samples they must be checked against actual loads. The trees included in a sale may have a wider range in diameter at breast height than those in this study. Because seasonal variation in tree-moisture content and possible site source of variation could affect weight scaling (Yerkes 1967), periodic sampling to verify or recalculate ratio weights or regression equations for a sale is necessary. Data from this report may be used to approximate the number of sample loads required at the start of a sale. The number of sample loads should be recalculated when actual sales data become available.

\section{Literature Cited}

Black Hills National Forest Products News. 1980. Sturgis to have waferboard plant. Hill City, S. Dak. January 18, 1980.

Blair, W. M. 1965. Weight-scaling pine sawlogs in Texas. Texas Forest Service Bulletin 52, 8 p. College Station. Service Bulletin 52, 8 p. College Station, Tex.

Donnelly, Dennis M., and Roland L. Barger. 1977. Weight scaling for southwestern ponderosa pine. USDA Forest Service Research Paper RM-181, 9 p. Rocky Mountain Forest and Range Experiment Station, Fort Collins, Colo.

Fasick, C. A., G. L. Tyre, and F. M. Riley, Jr. 1974. Weight-scaling tree length timber for veneer logs, saw logs, and pulpwood. Forest Products Journal 24(6):17-20.

Guttenberg, S., and C. A. Fasick. 1973. Scaling multiple products by weight. Forest Products Journal 23(5):34-37.
Guttenberg, S., D. L. Fassnacht, and W. C. Siegel. 1960. Weight-scaling southern pine saw logs. U.S. Department of Agriculture, Forest Service, Southern Forest Experiment Station, Occasional Paper 177, 6 p. New Orleans, La.

Landt, E. F., and R. O. Woodfin, Jr. 1959. Pulpwood characteristics of Black Hills ponderosa pine. TAPPI 42(10):809-812.

Lothner, David C., Richard M. Marden, and Edwin Kallio. 1974. Weight-volume relationships of aspen and winter cut black spruce pulpwood. USDA Forest Service Research Note NC-174, 4 p. North Central Forest Experiment Station, St. Paul, Minn.

Markstrom, Donald C., and Vern P. Yerkes. 1972. Specific gravity variation with height in Black Hills ponderosa pine. USDA Forest Service Research Note RM-213, 4 p. Rocky Mountain Forest and Range Experiment Station, Fort Collins, Colo.

Myers, Clifford A. 1960. Estimating oven-dry weight of pulpwood in standing ponderosa pine. Journal of Forestry 58(11):889-891.

Row, C., and C. Fasick. 1966. Weight-scale tables by electronic computer. Forest Products Journal 16(8):41-45.

Row, C., and S. Guttenberg. 1966. Determining weightvolume realtionships for saw logs. Forest Products Journal 16(5):39-47.

Schumacher, F. X. 1946. Volume-weight ratios of pine logs in the Virginia-North Carolina coastal plain. Journal of Forestry 44:583-586.

Taras, Michael A. 1956. Buying pulpwood by weight as compared with volume measure. Southeastern Forest Experiment Station Paper 74, 11 p. USDA Forest Service. Asheville, N.C.

Tyre, G. L., Clyde A. Fasick, Frank M. Riley, Jr., and Frank O. Lege. 1973. Program manual for producing weight-scaling conversion tables. USDA Forest Service General Technical Report SE-3, 43 p. Southeastern Forest Experiment Station, Asheville, N.C.

Weldon, D. 1967. Weight-scaling truckloads of hardwood and mixed pine and hardwood sawlogs. Texas Forest Service Bulletin 53, 4 p. College Station.

Wensel, L. C. 1974. Estimators for use in weight scaling of sawlogs. California Agricultural Experiment Station Bulletin 866, 24 p. Berkeley, Calif.

Yerkes, Vern P. 1966. Weight and cubic-foot relationships for Black Hills ponderosa pine sawlogs. USDA Forest Service Research Note RM-78, 4 p. Rocky Mountain Forest and Range Experiment Station, Fort Collins, Colo.

Yerkes, Vern P. 1967. Effect of seasonal moisture variation and log storage on weight of Black Hills ponderosa pine. USDA Forest Service Research Note RM-96, 8 p. Rocky Mountain Forest and Range Experiment Station, Fort Collins, Colo. 


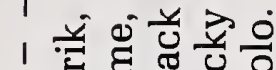
1 䒕西次 1 小 i U \& Ð

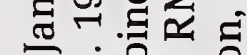
㑒 戸 미들 동 믈 홀

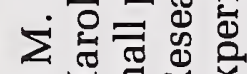

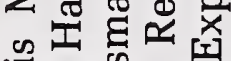

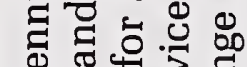
口 $\therefore$ 离 1 -

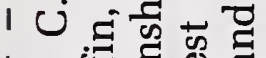
I 음 1 党 8

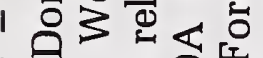
品元圷

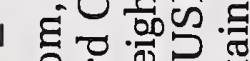
1 元引

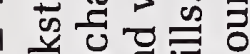

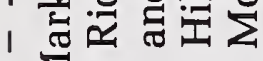
i

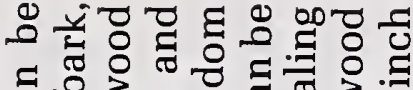

త్ర ช 范它

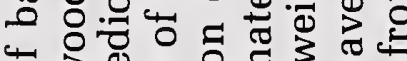

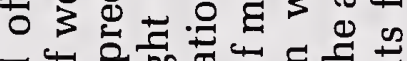
눙 ส

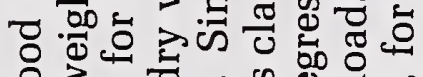
3둥 उ

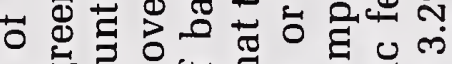
\# .00 హ.

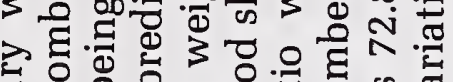
잉ำ

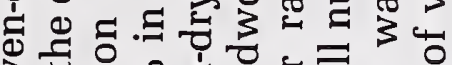

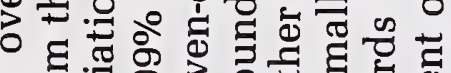
ช ส

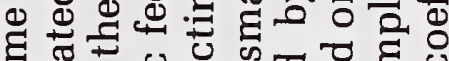

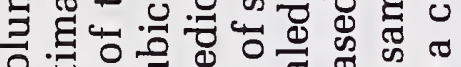

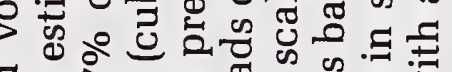

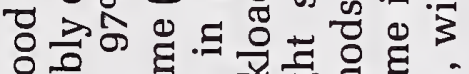

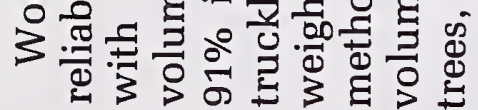

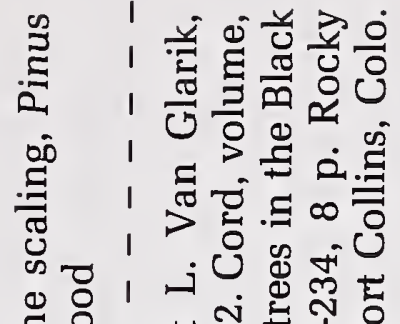

छ

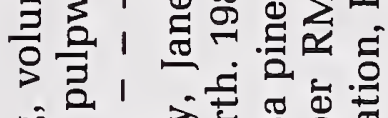

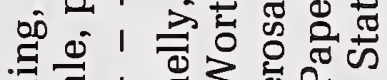

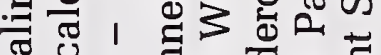

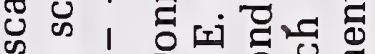

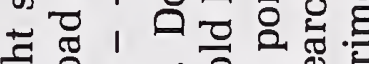

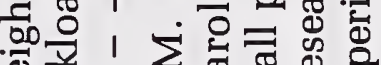

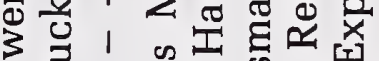

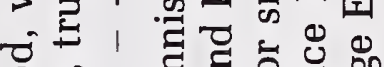
○ั। उ导,

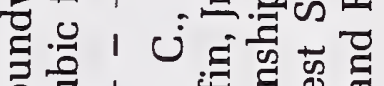

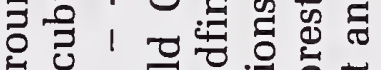

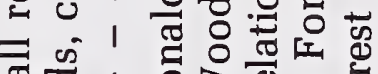
శี क 仓 ।

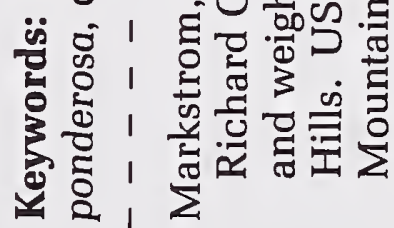

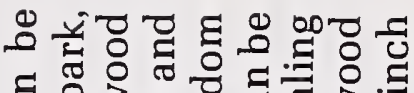

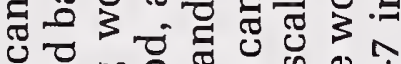

บ

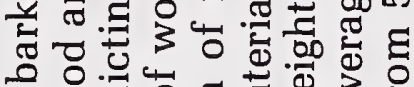

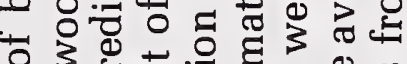
눙

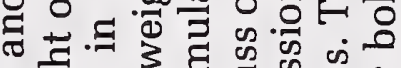

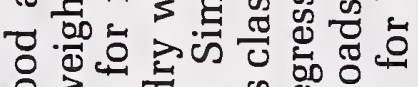
03 둥.

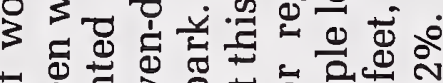

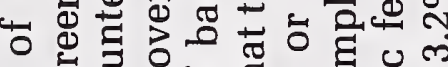
+ .00 3. $00.00 \%$

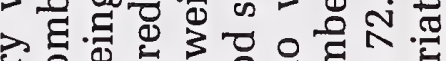

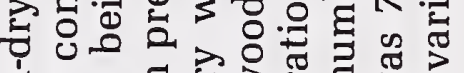

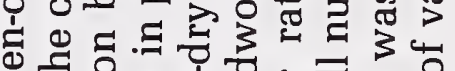

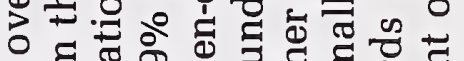

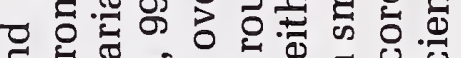

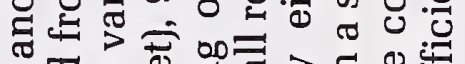
ฮั द्व

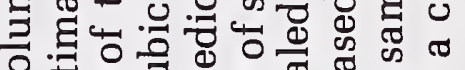

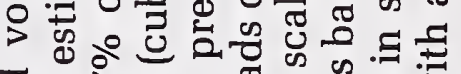

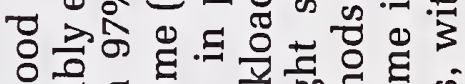

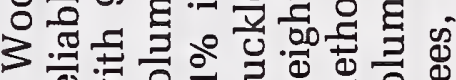

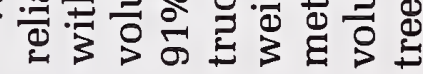

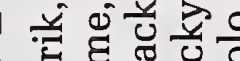

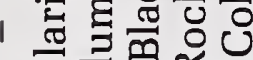
ठण $>\equiv$ , iU \& म Ð 䎡告 㝴它.9 귱유유 Ð引的

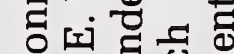
ด을

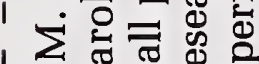
क旲医厌

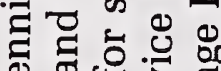
ฮั -

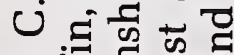
乙

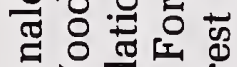

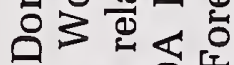

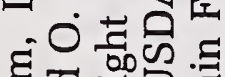
믕 믄

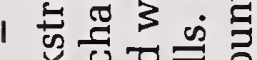

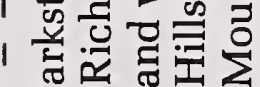
$1 \sum$

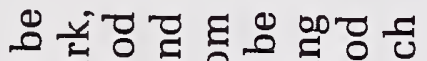

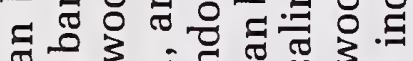
U。

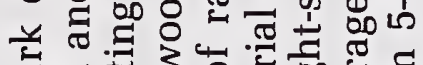

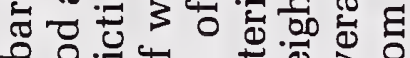

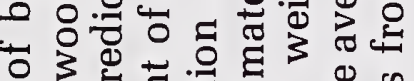
○

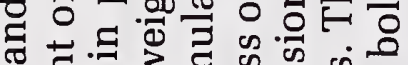
.0.

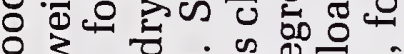

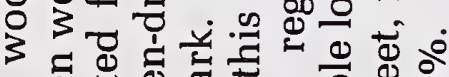

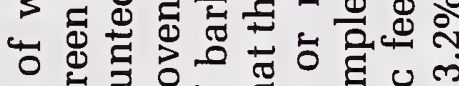

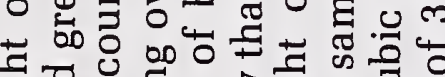

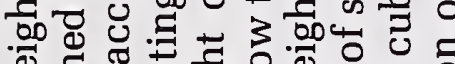
ब.

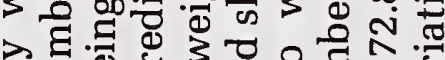

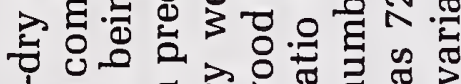

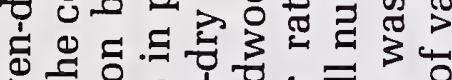

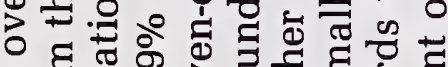

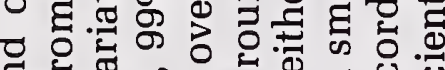

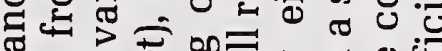

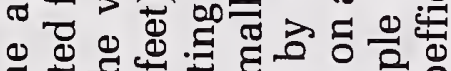
द्व त्ञ

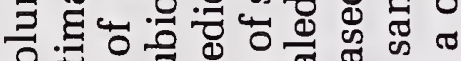

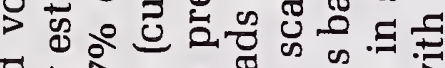

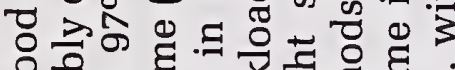

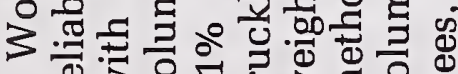

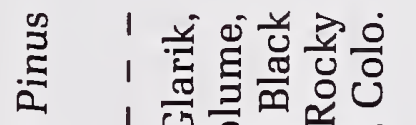
.0 1100 ชู 1 गี क 1 ; Ð 1 i ఏ引

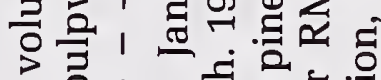

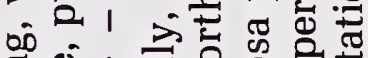
政। ठु 퓨 쥬

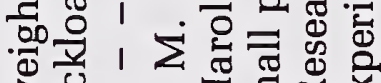

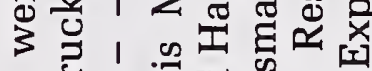
ชี

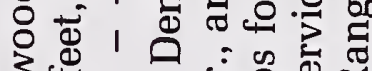

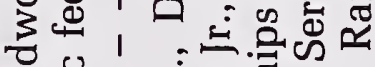

茟

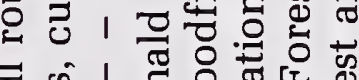

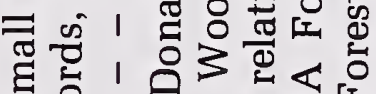
芯 1 is

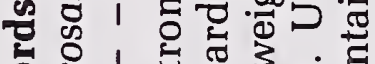

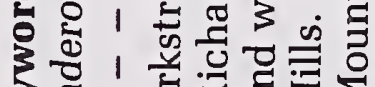

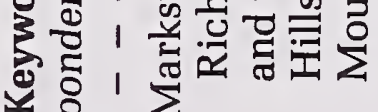

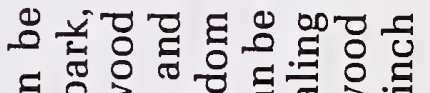

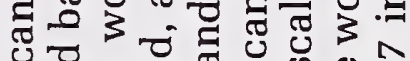

บ

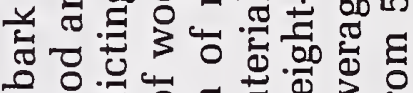
世啳

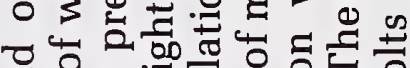

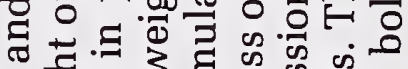

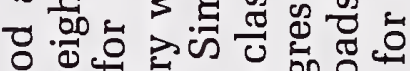
추 항 용으. ३

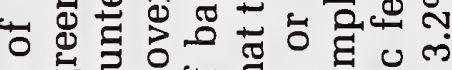

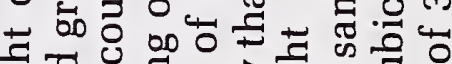
.00 3. 00.0003 $>$ ह

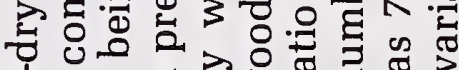

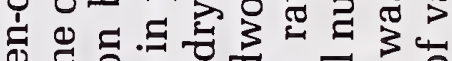

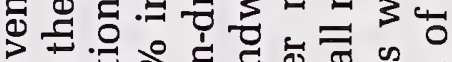
○ द्व 은 ส ๑ ఖ

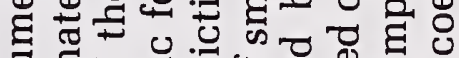

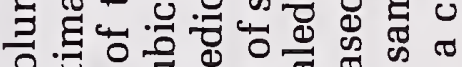

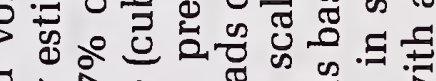

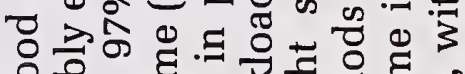

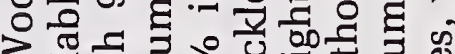

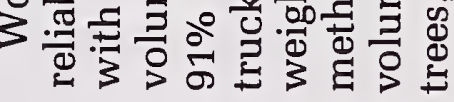

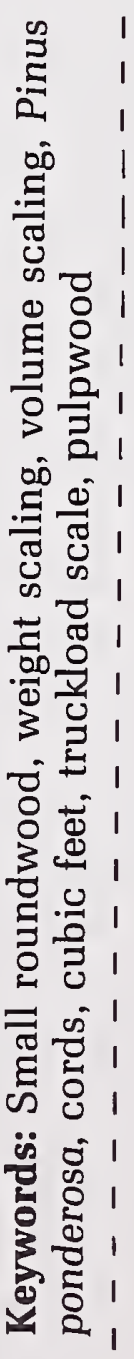




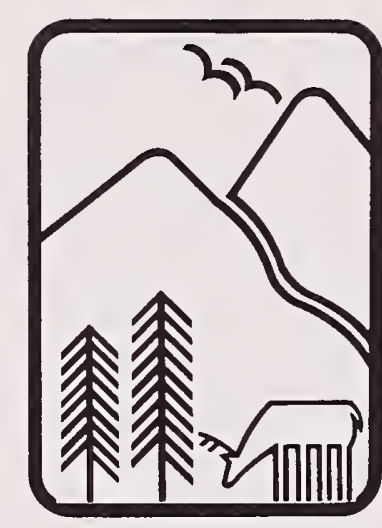

Rocky

Mountains

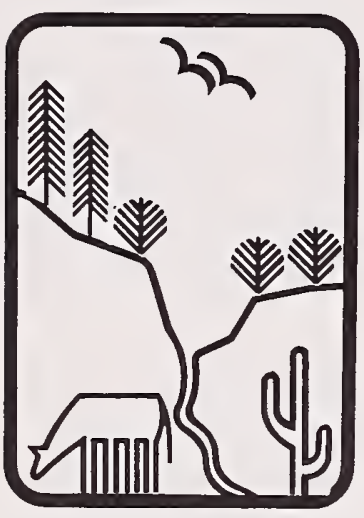

Southwest

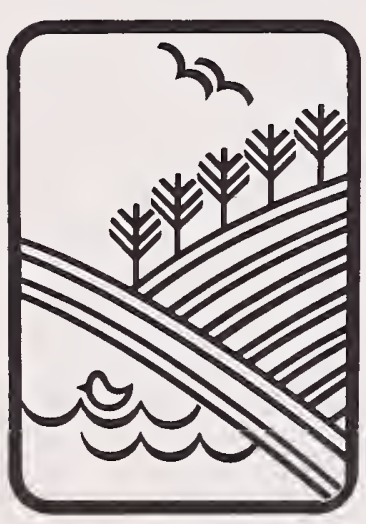

Great

Plains
U.S. Department of Agriculture Forest Service

Rocky Mountain Forest and Range Experiment Station

The Rocky Mountain Station is one of eight regional experiment stations, plus the Forest Products Laboratory and the Washington Office Staff, that make up the Forest Service research organization.

\section{RESEARCH FOCUS}

Research programs at the Rocky Mountain Station are coordinated with area universities and with other institutions. Many studies are conducted on a cooperative basis to accelerate solutions to problems involving range, water, wildlife and fish habitat, human and community development, timber, recreation, protection, and multiresource evaluation.

\section{RESEARCH LOCATIONS}

Research Work Units of the Rocky Mountain Station are operated in cooperation with universities in the following cities:
Albuquerque, New Mexico
Bottineau, North Dakota
Flagstaff, Arizona
Fort Collins, Colorado*
Laramie, Wyoming
Lincoln, Nebraska
Lubbock, Texas
Rapid City, South Dakota
Tempe, Arizona

*Station Headquarters: 240 W. Prospect St., Fort Collins, CO 80526 